
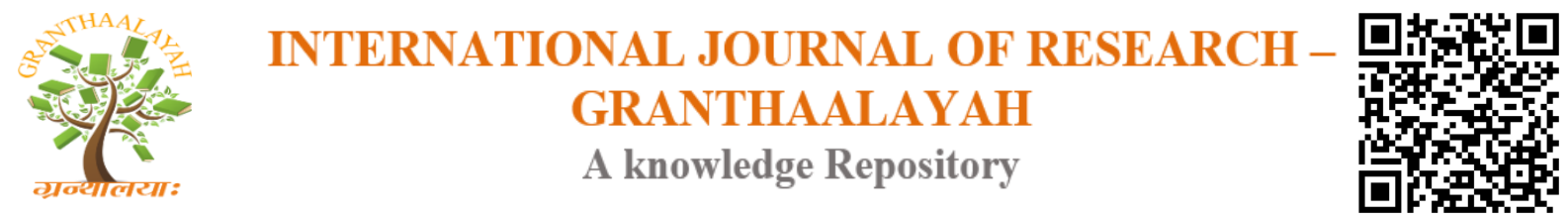

Management

\title{
A STUDY ON ORGANIZATIONAL CULTURE
}

\author{
S. Valentine Usha Kalaichelvi ${ }^{1}$, Dr. Auxilia Antony ${ }^{2}$, Dr. A. Nelson Vimalanathan ${ }^{3}$ \\ ${ }^{1}$ M.Com., M.Ed., M.Phil., SET.,(Ph.D), Assistant Professor, Department of Commerce. \\ Auxilium College, India \\ ${ }^{2}$ M.Com., M.Phil., Ph.D,. Head \& Assistant Professor, Department of Commerce Shift II, \\ Auxilium College, India \\ ${ }^{3}$ M.Com., M.Phil., Ph.D., Research Guide \& Supervisor, Voorhees College, India
}

\begin{abstract}
Organizational Culture is defined as the values and behaviors that contribute to the unique social and psychological environment of the organization. Organizational culture includes an organizations expectations, experiences, philosophy and values that hold it together and is expressed in its self-image, inner workings, interactions with the outside world and future expectations. This article is going to study about the organizational culture.
\end{abstract}

Keywords: Organizational Culture; Values; Behaviors \& Expectations.

Cite This Article: S. Valentine Usha Kalaichelvi, Dr. Auxilia Antony, and Dr. A. Nelson Vimalanathan. (2017). "A STUDY ON ORGANIZATIONAL CULTURE." International Journal of Research - Granthaalayah, 5(8:SE), 91-95.

\section{Introduction}

- Robbie Katanga.

\section{"CULTURE IS HOW ORGANIZATIONS DO THINGS."}

"Organizational Culture defines a jointly shared description of an organization from within." - Bruce Perron.

Culture is a process of "Sense Making" in organizations. "Sense Making" has been defined as a "collaborative process of creating awareness and understanding out of different individuals' perspective and varied interests." Organization Culture is the sum of values and rituals which serve as "glue" to integrate the members of the organization.

Alan Adler quotes it as a civilization in the work place. An organizations' culture can be related to the success rate of projects in a number of areas, including processes, management style, time management and training. 
Barriers and Problems Identified Related to Organizational Culture:

1) The project planners in an organization face too many commitments to which they have to be receptive to proposed adjustments in design.

2) There is lack of consistency in the quality of the project documents and weak, ineffective guidelines for their preparation.

3) Absence of common standards for project quality and of a mechanism for assuring it.

4) There is inadequate attention to adopting a consultative and participatory approach in working with partners and stakeholders.

5) Insufficient internal staff allocations and poor use of professional and technical capacities to supervise project appraisal, design, management and monitoring.

6) Insufficiency in integrating organizational processes and the needs of project planning and implementation.

\section{Quality Culture}

"Quality lies in Culture.

Values are what constitute through quality."

The major areas of concern for business are -"Quality" and "Productivity".

The basic foundation of any quality improvement is to develop a "quality culture" or mindset within the organization and integrate throughout the company. A quality- focused culture creates a healthy work environment and this leads to satisfied customers.

Quality Culture starts with good leadership that understands and beliefs the implication of the organization system and knows the needs and necessity of the customers, thus leading to success. A good understanding gives rise to positive internal environment. There is a continuous improvement of processes resulting in a healthy working environment, satisfied customers and by-large, a growing and profit earning company.

\section{Five Main Ingredients for Quality Culture}

1) A sense of togetherness- $\{$ which includes the company, suppliers and customers $\}$

2) A sense of Openness- Honesty - a culture of listening to each other.

3) A sense of Accessibility - leaders be accessible and open to share information on company's future goals and plans of development.

4) A sense of improvement - stop blaming and start working out on the problems and walk towards improvement.

5) A sense of achievement - every process is a learning experience. There are no successes or failures.

Organizational culture affect the way people and group interact with each other, with clients and stakeholders. There is a set of shared understanding, norms, values, attitudes and beliefs of an organization. Human being is the founder and valuable source of all organizations.

The Basic Factors that create an organizational culture are:

a) Founders - who make the final decisions in an organization. They have an important basic role in the formation and growth of the organization. 
b) Environment - Has a critical and indirect role in creation of an organizational culture.

c) Organizational Personnel - compatible persons who equip to the changing environment of the organizations are necessary.

The Three Basic cultural Perspective is:

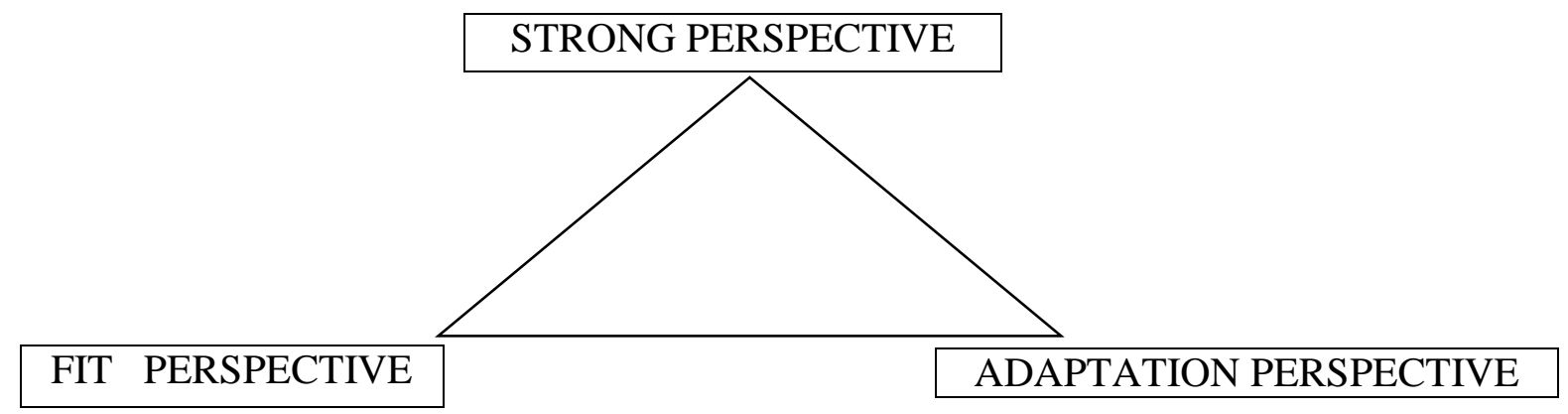

An organization with strong culture performs better than the other organizations. A fit perspective highlights the validity of the organization. It also helps in explaining the short term performances. An adaptive perspective shows the confidence and risk taking capacity among the employees. In today's fast growing technology, every individual is affected by the culture in which he lives. An individual working in a well-established, organization is taught the values, beliefs and expected behaviors of that organization. This definitely has a significant impact on the employee turnover and his job performance.

\section{Six Major Dimensions of Organizational Culture}

\section{1) Means Vs God Oriented}

A means-oriented culture places importance on "how work gets done". It emphasizes on avoiding risk. The focus is on the way people do work. On the other hand, there is a goaloriented culture which identifies with "what work gets done". This is more effective than those with means-oriented cultures.

2) Internal - Vs -External culture

The employees under internally driven culture see themselves as experts. They feel they know "what is best for the clients" and act accordingly. On the contrary, the externally driven cultures are very customer oriented and do whatever the customer wants. The mantra is "the customer is always right".

3) Easy going-Vs-strict work discipline

In an easy going culture, the approach to work is informal, loose, unpredictable and they facilitate high level of innovation. But in a strict culture, there is fair amount of planning leading to efficiency and productivity. There in delegation of work with detailed instructions.

\section{4) Local-Vs-Professional culture}

There is a low level of diversity in a local culture. There is great amount of predictability. In a professional culture, employees identify with their profession on the content of the work.

6) Open-Vs-Closed System

People are inclusive to the newcomers' ideas and approach. The leaders and managers are approachable. In a closed system it is more exclusive. The newcomers have to prove themselves. 


\section{7) Employee-Vs-Work centered}

In an employee centered management culture, leaders take responsibility for the welfare and satisfaction of their employees. They take it at the expense of productivity. But in a work centered culture, the focus is on high task performance, at the expense of the employees. There is low level of empathy for personal problem. Most of the time, even our preferences and company's cultures are more moderate and seem to fit-in somewhere in the extremes of the cultures mentioned above. But study reveals that these dimensions of organizational culture are neither good nor bad.

\section{Summary}

Organization culture represents a common perception shared by all the members of an organization. In an increasingly global business world, where different teams work across borders, understanding different work culture is the key to success.

The organization culture in India is totally different form rest of the world. The first thing that comes in our minds are the "myths" that prevails about the so-called "differences". The relationship that prevails between the boss and the subordinates. There has always been a very formal and hierarchal relationship. This may vary from company to company.

There is a fair amount of time spent on succession planning and talent management by many developing companies in India. Organizational culture is the shared beliefs, values, attitudes and behavior patterns that characterize the members of an organization.

The right organizational culture is the most important factor for a good knowledge management. It can be planned and structured partly.

\section{References}

[1] Abinash Panda And R. K. Gupta "Studying Organizational Culture: HICOM" Management Review.

[2] Edgar H.Schein "Organizational Culture and Leadership"

[3] Golden, S. A. R. (2011). An Analysis Of Mental Stress In Heavy Alloy Penetrator Project, Tiruchirappalli. SELP Journal of Social Science, 13.

[4] Golden, S. A. R. (2017). Recent Research in Social Sciences \& Humanities. EduPedia Publications (P) Ltd.

[5] Golden, S. A. R., Regi, S. B., \& Franco, C. E. (2014). A study on Impact of Information Technology (IT) in Modern Banking Sector. Golden Research Thoughts, 3(11), 1.

[6] Gupta R.N. "Principles Of Management" S. Chand \& Co., New Delhi .

[7] Regi, S. B., \& Golden, S. A. R. (2014). A Study On Attitude Of Employee Towards Working Environment With Special Reference To RR Pvt Ltd. Review Of Research, 2 (2), 1, 5.

[8] Regi, S. B., \& Golden, S. A. R. (2014). Attitude of Rural People Towards Technology Inclusion In Banking Services At Tirunelveli District. IGJAE-Indo Global Journal Of Applied Management Science, 2 (2).

[9] Regi, S. B., \& Golden, S. A. R. (2014). Attitude of Rural People Towards Technology Inclusion In Banking Services At Tirunelveli District. IGJAE-Indo Global Journal Of Applied Management Science, 2 (2). 
[10] Regi, S. B., Golden, S. A. R., \& Franco, C. E. (2014). Employee Perception Towards Effectiveness Of Hr Practices In Public Sector Banks In Tirunelveli District. Tactful Management Research Journal, 2(6), 1-4.

[11] www.managementstudyguide.com/organizationculture.htm.

[12] www.quickbase.com 